\title{
Computer Education in Lebanon
}

\author{
Hussein M. Yaghi \\ American University of Beirut
}

\begin{abstract}
This article summarizes the results of a nation-wide study that investigated the status of computer education in the Lebanese schools. The basic observation was that schools in the governmental sector were not using computers at all, however, computer education was making a good appearance in the private schools especially after the cease of the war in the country. Like other schools in many places of the world, the computer-using schools in Lebanon were suffering a great degree of confusion about how to integrate computer education into their educational programs in spite of using common software.
\end{abstract}

\section{Background}

Many researchers suggest introducing computer education to educational programs [1- 15]. Some researchers advocate educational computing as an essential element in preserving the welfare of children through educating them about relevant technologies and skills [3]. However, these researchers assert that "this noble goal has been little realized, not in the poorest of nations nor even in the wealthiest." [3 - page 7]. Furthermore, it seems that there is a lack of consensus among researchers about what constitutes a computer education program that can be recommended to schools [16]. Some researchers promote teaching the students useful computer-related skills such as word processing and the construction of electronic spreadsheets and databases [12]. Other researchers defend the use of computers as tools of exploration, research, and investigation in school work because computers encourage experimentation, new discoveries and new ways to solve problems $[2,8]$. While some researchers strongly advocate teaching programming $[9,10,12]$ others suggest to eliminate programming from computer education programs for the sake of concentrating on teaching computer applications[17].

Since the present study is a comprehensive survey of the use of computers in schools, it was necessary to examine various aspects of computer-based education which may require involving the students to perform some or all of the following activities proportional to the capacity of students in each grade: (1) to use computers as instructional tools to deliver instruction in different subject matters using computer assisted instruction (CAI) or computer-based instruction (CBI); (2) to train students on skills such as word processing, spreadsheeting, and data base management; (3) to create an environment that promotes higher-order thinking skills through prograrnming $[1,6,9,10]$; (4) to empower the teacher with performance support system that helps in conducting and organizing different educational activities; And (5) to use the computer as an educational subject by itself.

\section{The Present Study}

The primary goal was to quantify computer education in Lebanon. The information in this paper was gathered during the academic year 1994-1995. The scope of investigation was all schools in Lebanon, and the objectives were: (1) to collect quantitative information about the availability of computers in the Lebanese schools, (2) to identify the existing computer setups in terms of hardware 
and software and the qualifications of the personnel involved in computer education programs, and (3) To identify the trends of using computers in the Lebanese schools.

\section{Sampling}

We used the official list of schools provided by CERD (the Center for Educational Research and Development) to select a random sample that represents the different types of schools in all regions of Lebanon. Public schools which constitute $51 \%$ of the schools and enroll only31\% of the students were not included in the sample selection because it was known to us that they don't use computers [18]. The random selection produced a sample of 358 schools that enroll about 186,000 students made of 298 private schools and 60 semi-private schools. The proportions of school types in the sample approximates their proportions in the population of schools in the country.

\section{Instrumentation}

A questionnaire was developed and used to collect the needed data from the schools of the sample. It consisted of 102 items: Ten for general information about the school; 34 about computers and peripherals setup and type of software used; 58 about the manner in which computers were used in the school in teaching computer skills. The questionnaires were completed by the research team through interviewing the concerned individuals in each school.

\section{Results and Discussion}

The collected information includes: computer hardware and peripherals in use, educational software in use, the qualifications of the personnel involved in computer education programs, and how computers are used in the in the schools.

\section{c omputer Hardware}

We found that 206, or $57 \%$ of the schools were using computers among the 358 schools of the sample. They were using 3,507 computers with a mean of 17 computers per school. If we reflect that on all schools in the country we estimate that there are about 660 computer-using schools in Lebanon since the total number of private and semi-private schools is 1,159 and the public schools don't use computers. We can estimate that there are slightly more than 11,000 computers in all schools (total population of the country is about 3.5 millions, total number of schools is 2,446). However, the distribution of these computers is greatly disproportionate: $96 \%$ of them are being used by $65 \%$ of the private schools, and only $4 \%$ are being used by $18 \%$ of the semi-private schools. Students of the public schools are deprived from computer education at their schools except in a few scattered cases. If we consider all types of schools in Lebanon, then the percentage of computer-using schools drops to about $23 \%$ which means that more than $3 / 4$ of the students in Lebanon do not have access to computers.

\section{Figure 1 \\ Comparing the proportions of schools that use computers to those that do not use computers in each school type.}

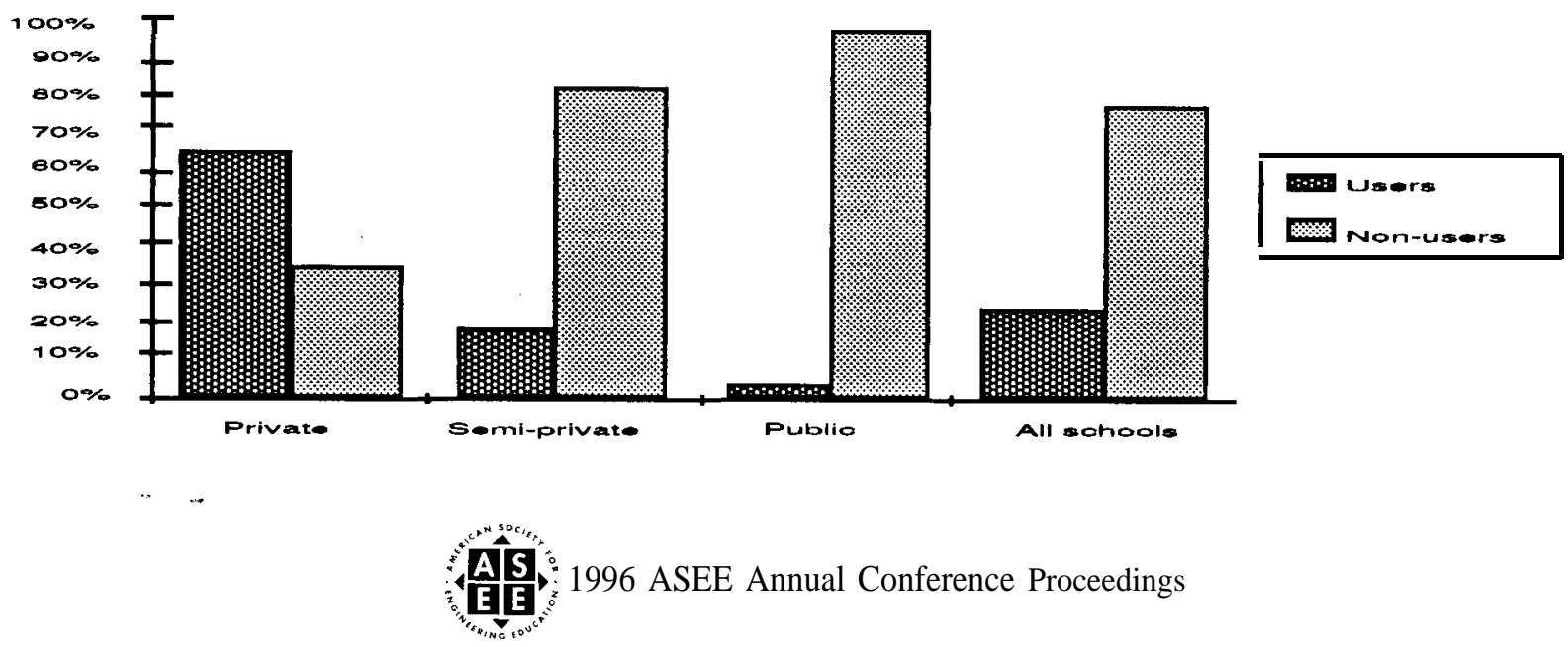


The density of students per computer is about 95 students/machine at the national level and 67 students/machine at the private schools.

\section{Software}

Since all types of schools depend heavily on non-Arabic languages in their instructional activities primarily French and English, schools find it easier to conduct computer related activities in French or in English rather than in Arabic. The same software known in the U.S.A. and in Europe may be found in Lebanese schools. However, some schools do teach Arabic computer applications especially Arabic word processing.

Possession of original software is generally poor at the Lebanese schools. The majority of the schools $(70 \%)$ said they do not own any original software beyond the operating systems, and only a small number of schools said that they own more than 100 pieces of original software including original educational CD-ROMs. The software found in the Lebanese schools are the same found in the U.S. and in Western Europe except for a small number of Arabic or "arabized" software.

The decisions about the content of computer education activities were scattered among school principals and the computer teacher jointly $(37 \%)$, the computer teachers alone(33\%), and the school principal alone (23\%). Subject matter teachers rarely interfere in such decisions. Table 1 shows the percentages of the decision makers about the content of computer education programs.

\section{Table 1.}

\section{Proportions of decision makers about content.}

\begin{tabular}{|l|l|}
\hline Position & Percentage \\
\hline School administrator and computer teacher & $37 \%$ \\
\hline Computer teacher alone & $33 \%$ \\
\hline School administrator alone & $23 \%$ \\
\hline $\begin{array}{l}\text { School administrator and subject matter } \\
\text { teacher }\end{array}$ & $4 \%$ \\
\hline Subject matter teacher alone & $2 \%$ \\
\hline Computer teacher and subject matter teacher & $1 \%$ \\
\hline
\end{tabular}

Perhaps the distribution of the decisions between different parties reflects the lack of a central reference for computer education.

\section{Personnel}

The dominant pattern was that computer education activities were handled by individuals with technical qualifications who lacked educational training. We found that nearly all persons who were in charge of computer labs or conducting teaching were either hardware engineers or software programmers. Most schools $(81 \%)$ were having full-time employees with computer science or computer engineering degrees. About $12 \%$ of these employees have masters degrees, $50 \%$ of them have BS/BE degrees, and31 \% of them have two-year diplomas. Most schools (70\%) were having the same person working as computer lab supervisor and computer teacher. Perhaps the computer teachers and computer lab supervisors technical qualifications explain the tendency in giving more weight to the technical skills in the computer education programs at the Lebanese schools.

As for all teachers general computing abilities, $48 \%$ of the schools said none of their teachers, other than the computer teacher, was able to use computers. This means that about $31 \%$ of the private schools teachers were able to use computers and only about $15 \%$ of all teachers in Lebanon were able to use computers in any task, Moreover, access to computer facilities especially printers, for those who can use computers, was extremely limited. 


\section{Computer Education Activities}

Most computer-using schools $(68 \%)$ started their computer education programs at the elementary level, $10 \%$ started at the pre-school level, $20 \%$ started at the intermediate level, and $2 \%$ started at the secondary level.

The mean of computer education periods per week was 1.4 and the mode was one period. Most schools $(\mathbf{7 7 \%})$ did not provide computer education services to their students beyond the regular teaching hours.

The surveyed computer education activities were grouped into three categories: (1) training on computer skills, (2) teaching subject matters through computers, and (3) teaching about computers.

\section{Teaching computer skills}

The reported skills include: keyboarding, operating the computer, word processing, spreadsheeting, database management, and programming. There was a wide range in the frequency of teaching these skills. The most frequent skill was, naturally, keyboarding (90\%), followed by operating system (62\%), then programming (59910), English word processing (51910), French word processing (45\%), Arabic word processing (33\%), data base management (17\%), and finally spreadsheet $(10 \%)$. Table 2 shows the computer skills and the percentage of the schools that apply each of these skills in their computer education programs.

\section{Table 2.}

\section{Proportions of teaching computer skills.}

\begin{tabular}{|l|l|}
\hline Skill & Percentage \\
\hline Kevboarding & I 93\% \\
\hline Opcrating system & $62 \%$ \\
\hline Programming & $\mathbf{5 9 \%}$ \\
\hline English word processing & $51 \%$ \\
\hline French word processing & $45 \%$ \\
\hline Arabic word processing & $33 \%$ \\
\hline Data base & $17 \%$ \\
\hline Spreadsheet & $16 \%$ \\
\hline
\end{tabular}

Though the basic computer skills are being taught at the Lebanese schools, which is consistent with what's being taught elsewhere in the world, the frequency of teaching these skills is different. It is for example lower than what is being practiced in the U.S. schools. The U.S. schools used computers for text processing (93\%), drill and practice (92\%), educational games (91\%), programming and operating system (84\%), communications (49\%), and multimedia (25\%) [15]. Still OTA reported about students in the U.S. conducting educational tasks using advanced multimedia techniques locally or via networks [8].

\section{Teaching through computer.}

The investigated activities in this category involved using CBI or CAI in teaching different subject matters. On the average about $31 \%$ of the computer-using schools said they were using computers in teaching or in drill and practice exercises in different subject matters. The most frequently used was CAI in math exercises (53\%), then science exercises (44\%), French Language exercises (37\%), English language exercises (25\%), Social studies (23\%), visual arts (22\%), and lastly Arabic language (10\%). The computers were rarely used in CBI activities except for some schools which reported using them in teaching some mathematical concepts. The relatively higher frequency of using computers in science and math activities is perhaps rooted in the misconception that computers are more associated with math and sciences. Table 3 shows the different subject matters and the percentages of the schools that apply computers whether in teaching or in drill and practice exercises. 


\section{Table 3.}

\section{Proportions of using $\mathrm{CAI} / \mathrm{CBI}$ in subject matters.}

\begin{tabular}{|l|l|}
\hline Subject matter & Percentage \\
\hline Mathematics & $53 \%$ \\
\hline Sciences & $44 \%$ \\
\hline French language & $37 \%$ \\
\hline English language & $25 \%$ \\
\hline Social studies (SS) & $23 \%$ \\
\hline Arts & $22 \%$ \\
\hline Arabic language & $110 \%$ \\
\hline
\end{tabular}

Knowing that the average weekly periods dedicated for all computer education activities was about 1.4 periods, then we can easily conclude that time devoted for CBI and CAI activities was very low even if it takes the whole dedicated time. Thus, it is safe to conclude that the impact of CAI and CBI in education in Lebanon is still very limited.

\section{Teaching about computers}

Sixty one percent $(61 \%)$ of the schools said they dedicate time to teach their students the importance of computers in modem life and to teach them about the computer's hardware and software components and concepts. However, this dedicated time was too short to satisfy the topics.

\section{Conclusion}

The basic remark is that Lebanese schools are trying to adopt computer education, however in a modest and nearly chaotic manner. Almost no two schools were having the same computer education program. Each school was following its own way depending on available resources. Unlike other subjects of the traditional curriculum, there is no unified curriculum for computer education. However, some common trends may be found which may constitute the backbone of a computer education curriculum. Needles to say that the components that curriculum should be carefully crafted to suit grade levels and students abilities.

Another striking observation was that only about $10 \%$ of the teachers in the computer-using schools said they are able to use computers. This percentage is expected to be even lower in the noncomputer-using schools. One can conclude that it could be a hopeless case to try to introduce all aspects of computer education without massive teacher training both inservice and preservice. How can teachers be expected to use CBI, CAI and teach computer skills if they do not know how to use computer. In fact, there are schools in the country who became aware of this problem and started training all their teachers on different computer skills. Also there are universities that started to teach specialized computer education courses and we may witness the establishment of specialized complete computer education programs at some of the countries universities and teacher training colleges.

The third basic remark was that the time allotted for computer education activities was too short. The frequency of using the computers as support devices in teaching and learning different subjects was also limited, and so was the amount of time dedicated for that. Therefore, longer and more frequent access time slots should be thought of when planning for computer education programs.

Perhaps Lebanon is having a special opportunity to rebuild its educational system now with the huge reconstruction projects taking place in many domains after the cease of the civil war. The government has plans to renovate the educational system, and these plans should address the technology related issues. 


\section{References}

[1] Becker, H.J. (1992). Computer Education. In M.C. Alkin (cd.), Encyclopedia of Educational Research, (pp.232-235). New York: Macmillan.

[2] Bonner, p. (1984). Toward a More Thoughtful Use of Computers in Education. Personal Computing, 8 153-161.

[31 Cavalier, R. \& Reeves T.C. (1993). International Perspectives on the Impact of Computing in Education: Introduction to Special Issue. Educational Technology, 33 (9), 7-10.

[4] Collis, B. (1993). The Impact of Computing in Education in Europe. Educational Technology, 33 (9) 37-41.

[5] Ely, D.P. (1993). Computers in Schools and Universities in the United States of America. Educational Technology, 33 (9) 53-57.

[6] Jonassen, D. H. (1989). Mindtools: Liberating Intellectual Force. Educational Technology, 39 (1), 23-29.

[7] Kearsly, G., Hunter, B., \& Furlong, M. (1992). We Teach With Technology: New Visions for Education. Wilsonville, OR: Franklin, Beedle \& Associates.

[8] O’Neil, J. (1995). Teachers and Technology: Potential and Pitfalls. Educational Leadership, 53 (2), 10-12.

[9] Papert, S. (1980). Windstorms: Children, Computers, and Powerful Ideas. New York: BasicBooks.

[10] Papert, S. (1993). The children's Machine: Rethinking in the Age of the Computer. New York: BasicBooks.

[11] Plomp, T., \& Pelgrum, W.J. (1990). Introduction of Computers in Education: State of the Art in Eight Countries. Paper presented at EURIT 90, Herning, Denmark, April, 1990.

[12] Randhawa, B. S.\& Hunt, D. (1984). Computers and Computer Literacy in Contemporary Psychological, Socio-Economical and Educational Context. Association for Data Systems Journal, 17(1) $1-13$.

[13] Reeves, T.C. (1993). Pseudoscience in Computer-Based Instruction: The Case of Learner Control Research. Journal of Computer-Based-Instruction, 20 (2), 39-46.

[14] Rosen, L.D. \& Weil M.M. (1995). Computer Availability, Computer Experience and Technophobia Among Public School Teachers. Computer in Human Behavior, 11 (1) 9-31.

[15] Sheingold, K., \& Hadley, M. (1990). Accomplished Teachers: Integrating Computers into Classroom Practice. New York: Center for Technology in Education, Bank STREET College of Education.

[16] Woodrow, J. (1994). The Development of Computer-Related Attitudes of Secondary Students. Journal of Educational Computing Research, 11 (4), 307-337

[17] Butler, P. A., (1985). Research Notes. Journal of Educational Computing Research, 1, 121-125.

[18] CERD, (1994). Statistical Report for 1993-1994 School Year. Center for Educational Research. Beirut, Lebanon.

\section{HUSSEIN YAGHI}

\section{Biography:}

Hussein Yaghi was born in 1950 in Lebanon. He received his Ph.D. in Instructional Technology from the University of Southern California (USC), 1986. He managed the Personal Computing Department and the Department of Training and Technological Development of Kuwait University from 1987 to 1990. Since October 1990 he is working as an assistant professor at the Department of Education of the American University of Beirut, Lebanon. His research interests are computers in education, computer graphics, statistics, and the visual arts. He published articles about computers and multimedia in education and training. He also produced a good number of art works. 